\title{
Sterile-filtered saliva is a strong inducer of IL-6 and IL-8 in oral fibroblasts
}

\author{
Barbara Cvikl • Adrian Lussi • Andreas Moritz • \\ Anton Sculean • Reinhard Gruber
}

Received: 7 November 2013 / Accepted: 14 March 2014 /Published online: 29 March 2014

(C) Springer-Verlag Berlin Heidelberg 2014

\begin{abstract}
Objectives Saliva has been implicated to support oral wound healing, a process that requires a transient inflammatory reaction. However, definitive proof that saliva can provoke an inflammatory response remained elusive.

Materials and methods We investigated the ability of freshly harvested and sterile-filtered saliva to cause an inflammatory response of oral fibroblasts and epithelial cells. The expression of cytokines and chemokines was assessed by microarray, RT-PCR, immunoassays, and Luminex technology. The involvement of signaling pathways was determined by Western blot analysis and pharmacologic inhibitors.

Results We report that sterile-filtered whole saliva was a potent inducer of IL- 6 and IL-8 in fibroblasts from the gingiva, the palate, and the periodontal ligament, but not of oral epithelial cells. This strong inflammatory response requires nuclear factor-kappa B and mitogen-activated protein kinase signaling. The pro-inflammatory capacity is heat stable and has a molecular weight of $<40 \mathrm{kDa}$. Genome-wide microarrays and Luminex technology further revealed that saliva
\end{abstract}

\section{B. Cvikl $\cdot$ A. Lussi $\cdot$ R. Gruber}

Department of Preventive, Restorative and Pediatric Dentistry,

School of Dental Medicine, University of Bern, Bern, Switzerland

B. Cvikl • R. Gruber $(\square)$

Laboratory of Oral Cell Biology, School of Dental Medicine,

University of Bern, Bern, Switzerland

e-mail: reinhard.gruber@zmk.unibe.ch

B. Cvikl • A. Moritz

Department of Conservative Dentistry and Periodontology, Medical

University of Vienna, Vienna, Austria

A. Sculean $\cdot$ R. Gruber

Department of Periodontology, School of Dental Medicine,

University of Bern, Bern, Switzerland substantially increased expression of other inflammatory genes and various chemokines. To preclude that the observed pro-inflammatory activity is the result of oral bacteria, sterile-filtered parotid saliva, collected under almost aseptic conditions, was used and also increased IL-6 and IL-8 expression in gingiva fibroblasts. The inflammatory response was, furthermore, independent of MYD88, an adapter protein of the Toll-like receptor signaling pathway.

Conclusions We conclude that saliva can provoke a robust inflammatory response in oral fibroblasts involving the classical nuclear factor-kappa B and mitogen-activated protein kinase signaling pathway.

Clinical relevance Since fibroblasts but not epithelial cells show a strong inflammatory response, saliva may support the innate immunity of defect sites exposing the oral connective tissue.

Keywords Saliva $\cdot$ Inflammation $\cdot$ Fibroblasts $\cdot$ Cytokines NFKB $\cdot$ Microarray $\cdot$ Luminex technology

\section{Introduction}

Saliva being produced by the submandibular and the parotid glands carries physiologic molecules including electrolytes, mucus, antibacterial compounds, enzymes, and growth factors [1]. Besides its function in lubrication and initiating food digestion, saliva proteins form the pellicle layer on enamel that supports mineralization [2] and biofilm formation [3]. Research has advanced in the biochemical characterization of pellicle proteins [4] and the adhesion of various types of bacteria [5]. Moreover, saliva is used for diagnostic purposes. The physiologic role of saliva becomes obvious at disease state, for example, in patients with Sjögren syndrome and patients 
receiving head and neck radiotherapy. Saliva clearly holds a myriad of functions, and revealing its multiple tasks remains a challenge.

Saliva has been implicated to support oral wound healing. Desalivated rodents showed impaired healing of extraction sites or palatal wounds [6,7]. Also, crude extracts of salivary glands change cell viability in vitro [8]. Whole saliva lowers the viability of the osteogenic MC3T3-E1 cell line; however, the cells failed to release significant amounts of inflammatory cytokines in response to saliva, e.g., interleukin-1 (IL-1) or tumor necrosis factor alpha. This missing significance was assumed by the authors as a consequence of interindividual release upon using saliva from different donors [9]. On the other hand, truncated lactoferrin isolated of whole saliva possesses inflammatory properties as shown by the increased IL-6 and IL-8 production of the epithelial human squamous carcinoma (HSC)-2 cells [10]. Thus, the data are somehow heterogeneous, which might be based on the use of different types of cells, from hard and soft tissue, and due to the fact that the cells were stimulated for varying times and with salivary components or whole saliva, respectively. Also, other components from saliva such as epidermal growth factor (EGF) [11], transforming growth factor (TGF)-beta [12], histatin [13], and cystatin [14] can provoke a cellular reaction. Saliva can thus cause a complex cellular response, including inflammation on the oral tissue.

Inflammation is a part of the innate immunity and ultimately linked with wound healing. The cytokines IL6 and IL-8, which are highly expressed at wound site, attract and activate immune cells [15]. IL-6 is mostly related to inflammation, host defense, and tissue injury [16], while IL-8 is known to be a very important proinflammatory mediator and chemoattractant [17]. In the oral cavity, gingiva and periodontal ligament fibroblasts are capable to produce IL-6 and IL-8 upon incubation with pro-inflammatory agents such as bacteria [18] and activation of pattern recognition receptors [19]. Saliva IL6 and IL-8, which are like other inflammatory cytokines mostly derived from gingival crevicular fluid or tissue exudates are increased in caries patients [20] and during gingival inflammation [21, 22], even though the link to periodontitis [23] and periimplantitis [24] is vague. These data support the association of saliva and the production of IL- 6 and IL- 8 in the oral cavity.

Surprisingly, and considering that many of the single components of saliva have been tested for their capacity to cause a cellular reaction [25], in vitro research with whole saliva is rare. Research with whole saliva, however, is particularly important because single components only partially reflect the complexity of the physiologic molecular cocktail. The purpose of the present study was therefore to test the hypothesis that freshly harvested sterilefiltered whole saliva is able to provoke an inflammatory response of oral cells in vitro.

\section{Material and methods}

Cells and stimulation of cells with saliva

Cells, which may come in contact with saliva in the oral cavity as well a monocytic cell line and a carcinoma cell line, were used to figure out possible different responses of the different cell types to saliva. For experiments with primary cells, cell pools made from cells of three different donors each were used. Human gingiva, palatal, and periodontal ligament fibroblasts were prepared from tissue grafts after approval (Kantonale Ethikkommission Bern) and informed consent by the donor were obtained. The donors were selected on the basis of the absence of previous history of inflammation. To isolate fibroblasts, tissue explants were cultivated in Dulbecco's modified Eagle medium (DMEM, Invitrogen Corporation, Carlsbad, CA) supplemented with $10 \%$ fetal calf serum (FCS; PAA Laboratories, Linz, Austria) and antibiotics (Invitrogen) at $37{ }^{\circ} \mathrm{C}, 5 \% \mathrm{CO}_{2}$, and $95 \%$ humidity. Fibroblasts that grew out from the explants and had not undergone more than five passages were used. U937, a human leukemic monocyte lymphoma cell line, and oral squamous cell carcinoma, HSC-2, were kindly provided by the Medical University of Vienna, Austria. Primary human gingival epithelial cells were obtained from CELLnTEC Advanced Cell Systems AG (Bern, Switzerland). Human gingiva, palatal, and periodontal ligament fibroblasts as well as U937, HSC-2, and primary human gingival epithelial cells were used in indicated experiments to investigate the response of various cell types to saliva. All other experiments were performed with a pool of human gingiva fibroblasts. Cells were plated in growth medium at 30,000 cells $/ \mathrm{cm}^{2}$ into culture dishes. The following day, cells were incubated in serum-free medium containing freshly prepared sterile-filtered whole saliva immediately after saliva collection. Cell incubation showed that 2 -fold but not 10 -fold dilution visually changes cell morphology (Fig. 1c). Thus, if not otherwise indicated, cells were exposed to saliva at the 10fold dilution and incubated for $6 \mathrm{~h}$ for expression analysis and $24 \mathrm{~h}$ for immunoassays.

Saliva sampling and treatment

Whole saliva was collected from donors, who were nonsmokers and had no oral inflammation, while chewing 
Fig. 1 Saliva stimulates IL-6 and IL-8 in various cell types of the oral cavity. Cells were incubated in serum containing medium at a density of 30,000 cells $/ \mathrm{cm}^{2}$. The following day, cells were incubated in serum-free medium containing saliva. Fibroblasts from the human gingiva $(G F)$, palatal $(P F)$, and periodontal ligament fibroblasts $(P D L)$ as well as oral squamous cell carcinoma ( $H S C$-2) and primary human gingival epithelial cells $(p E C)$ and a human leukemic monocyte lymphoma cell line (U937) were exposed to saliva. The fibroblastic cells showed a strong response to saliva as indicated by the $>10$-fold increase in the expression of IL-6 (black bars) and IL-8 (gray bars). The monocytic cell line and both epithelial cells, however, showed a rather moderate response with an increase below 10-fold (a). Doseresponse curves indicate that the maximal stimulation of the cytokines was reached at a dilution factor of approximately 10 -fold, with less expression at the 3-fold dilution (b). Saliva at a higher concentration caused severe damages, while saliva at the $1: 10$ dilution used in the present study provides no harm to the cells (c). A significant difference to unstimulated control was defined to be $p<0.05(* p<0.05)$

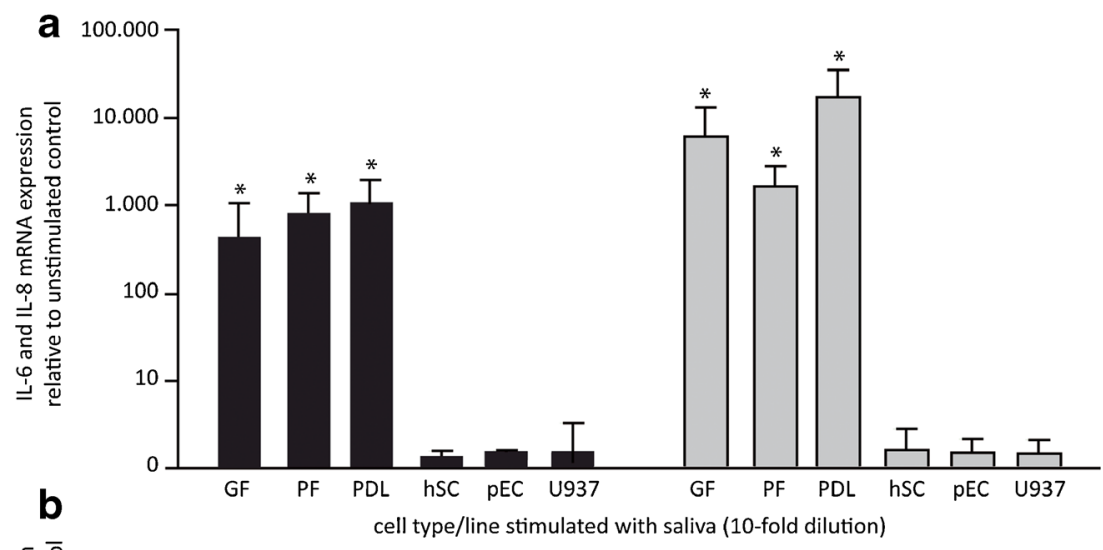

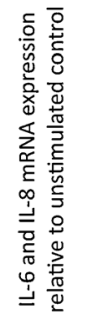

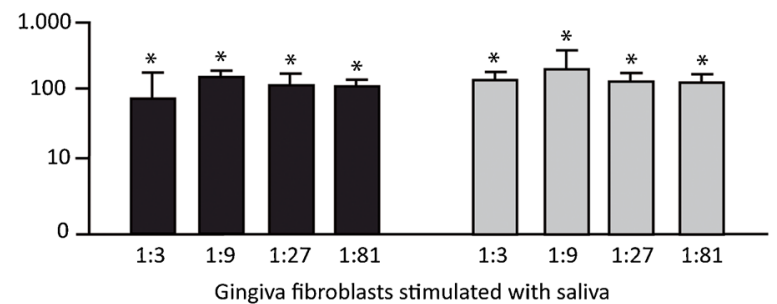

C

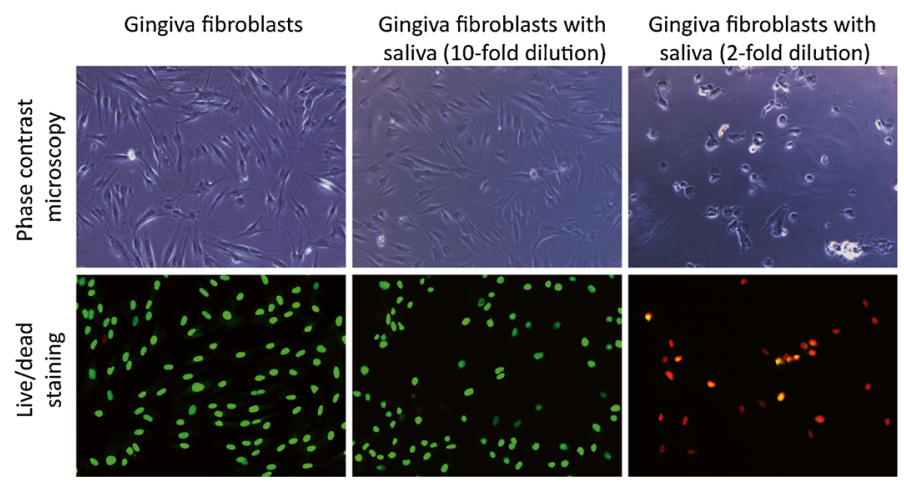

paraffin wax (Ivoclar Vivadent AG, Schaan, Liechtenstein). Donors provided their written informed consent to participate in this study. Saliva was collected between 09:00 and 11:00 a.m., and donors were abstained from

Table 1 Primer sequence of RTPCR

\begin{tabular}{llll}
\hline Gene & Forward primer & Reverse primer & Reference \\
\hline IL-6 & gaaaggagacatgtaacaagagt & gatttcaccaggcaagtct & {$[35]$} \\
IL-8 & aacttctccacaaccctctg & ttggcagccttcctgatttc & {$[36]$} \\
ICAM-1 & ccttcctcaccgtgtactgg & agcgtagggtaaggttcttgc & \\
CXCL1 & tcctgcatccccatagtta & cttcaggaacagccaccagt & \\
CXCL2 & cccatggttaagaaaatcatcg & cttcaggaacagccaccaat & \\
CXCL3 & aaatcatcgaaaagatactgaacaag & ggtaagggcagggaccac & \\
CXCL6 & gtccttcgggctccttgt & cagcacagcagagacaggac & \\
CCL7 & gaaagcctctgcagcacttc & aatctgtagcagcaggtagttgaa \\
CCL20 & gctgctttgatgtcagtgct & gcagtcaaagttgcttgctg & \\
PTGS2 & cttcacgcatcagttttcaag & tcaccgtaaatatgatttaagtccac \\
BCL2A1 & caggagaatggataaggcaaa & ccagccagatttaggttcaaa \\
\hline
\end{tabular}


eating and drinking for $1 \mathrm{~h}$ prior to collection. The local ethical board of the University of Bern approved sampling. Immediately after collection, saliva was centrifuged at $4,000 \times g$ for $5 \mathrm{~min}$. Saliva was filtered sterile (1 $\mathrm{ml}$ per $0.22 \mu \mathrm{m}$ PES syringe filter, TPP AG, Trasadingen, Switzerland) to remove viable microorganisms [26]. Samples were immediately used to stimulate cells.

Parotid saliva sampling and microbiological cultures

For indicated experiments, stimulated parotid saliva was harvested. After mouth rinse with $0.12 \%$ chlorhexidine gluconate, the parotid duct was wiped with a cotton swab with hydrogen peroxide. A lemon drop was sucked on the tongue, and after rejecting the first five drops, parotid saliva was collected with a sterile syringe. Undiluted parotid saliva was subjected to a blood agar and a lysogeny broth agar plate at a volume of $200 \mu$ l (dilution series was performed in preliminary tests). The number of colonies was determined after incubation at $37{ }^{\circ} \mathrm{C}$ for $48 \mathrm{~h}$. The limit of detection per plate was 1 colony-forming unit (CFU), which means $5 \mathrm{CFU} / \mathrm{ml}$. Sterile-filtered parotid saliva at a

Table 2 Saliva stimulates IL-6, IL-8, and cytokine protein expression $(\mathrm{pg} / \mathrm{ml})$ in various cell types of the oral cavity. All fibroblastic cells, independent of their origin, showed a robust response to saliva as indicated by the $>10$-fold increase in the expression of IL- 6 and IL- 8 , detected by ELISA technology. Luminex analysis (ProcartaPlex ${ }^{\mathrm{TM}}$ Multiplex 10-fold dilution was also used to stimulate human gingiva fibroblasts for $6 \mathrm{~h}$.

\section{Blocking of MYD88 and TLRs}

To further exclude that the inflammatory reaction induced by saliva is caused by microorganism and their products, myeloid differentiation primary response (MYD)88, an adapter protein of the Toll-like receptor signaling pathway, and the Toll-like receptors 2 and 4 themselves were blocked. Human gingiva fibroblasts were preincubated with MYD88 inhibitory peptide at $100 \mu \mathrm{M}$ for $24 \mathrm{~h}$ and Toll-like receptors (TLR)2 and TLR4 inhibitory peptide at $50 \mu \mathrm{M}$ for 1 hour, respectively. Afterwards sterile-filtered whole saliva in a 10-fold dilution was used to stimulate the cells for $6 \mathrm{~h}$, and expression of inflammatory genes was performed.

\section{Saliva treatment}

In order to understand more what components of saliva are responsible for the pro-inflammatory reaction of human gingiva fibroblasts, different saliva treatment methods were performed with sterile-filtered whole saliva

\begin{tabular}{|c|c|c|c|c|c|c|}
\hline \multicolumn{7}{|c|}{ ELISA $(n=1)$} \\
\hline & IL-6 w/o & IL-6 saliva & IL-8 w/o & \multicolumn{3}{|l|}{ IL-8 saliva } \\
\hline GF & 247 & 7,586 & 536 & \multicolumn{3}{|l|}{10,486} \\
\hline $\mathrm{PF}$ & 386 & 15,834 & 455 & \multicolumn{3}{|l|}{18,823} \\
\hline PDL & 234 & 5,069 & 132 & \multicolumn{3}{|l|}{7,473} \\
\hline $\mathrm{hSC}$ & 199 & 230 & 805 & \multicolumn{3}{|l|}{982} \\
\hline $\mathrm{pEC}$ & 182 & 760 & 727 & \multicolumn{3}{|l|}{750} \\
\hline U937 & 182 & 173 & 291 & \multicolumn{3}{|l|}{555} \\
\hline \multicolumn{7}{|c|}{ Luminex $(n=3)$} \\
\hline & IL-6 w/o & IL-6 saliva & IL-8 w/o & IL-8 saliva & $\mathrm{MCP}-3 \mathrm{w} / \mathrm{o}$ & MCP-3 saliva \\
\hline GF & $1,010( \pm 1,542)$ & $21,101( \pm 14,341)$ & n.d. & $3,364( \pm 3960)$ & n.d. & $190( \pm 245)$ \\
\hline $\mathrm{PF}$ & $158( \pm 335)$ & $4,207( \pm 1,101)$ & n.d. & $680( \pm 660)$ & n.d. & n.d. \\
\hline \multirow[t]{2}{*}{ PDL } & $198( \pm 34)$ & $11,821( \pm 14,419)$ & n.d. & $1,536( \pm 2,009)$ & n.d. & n.d. \\
\hline & GRO-a w/o & GRO-a saliva & MIP-3a w/o & MIP-3a saliva & GM-CSF w/o & GM-CSF saliva \\
\hline GF & $62( \pm 54)$ & $704( \pm 521)$ & n.d. & $31( \pm 53)$ & n.d. & $284( \pm 407)$ \\
\hline PF & $156( \pm 130)$ & $456( \pm 131)$ & n.d. & n.d. & n.d. & $175( \pm 7)$ \\
\hline PDL & n.d. & $140( \pm 83)$ & n.d. & n.d. & n.d. & n.d. \\
\hline
\end{tabular}

Data represent the mean plus standard deviation of three independent experiments

n.d. not detectable

Immunoassay, eBioscience Vienna, Austria) for human IL-6, human IL8, human GM-CSF, human GRO-alpha, human MCP-3, and human MIP3alpha showed statistically significant differences between untreated fibroblasts (w/o) and fibroblasts treated with saliva (saliva) 
Fig. 2 Sterile-prepared parotid saliva stimulates IL-6 and IL-8. Parotid saliva was prepared under aseptic conditions. This sterilefiltered parotid saliva increased IL-6 (black bars) and IL-8 (gray bars) expression in human gingiva fibroblasts ( $>10$-fold) (a). The number of colonies was less than $10^{2} / \mathrm{ml}$ (b). Blocking MYD88 and toll-like receptors 2 and 4, essential receptors in the signaling of lipoteichoic acid and lipopolysaccharides, had no effect on the strong pro-inflammatory activity of sterile-filtered saliva in gingiva fibroblasts $(\mathbf{c})$. A significant difference to unstimulated control was defined to be $p<0.05\left({ }^{*} p<0.05\right)$
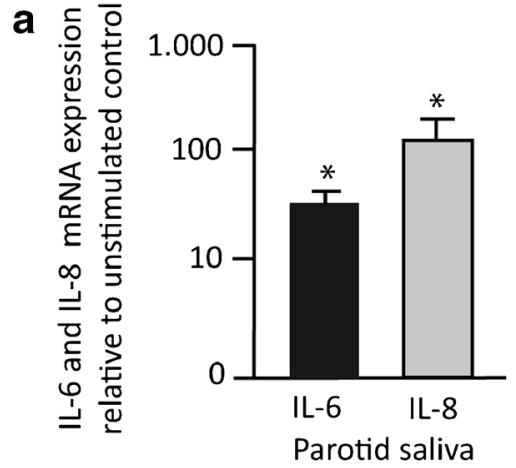

b

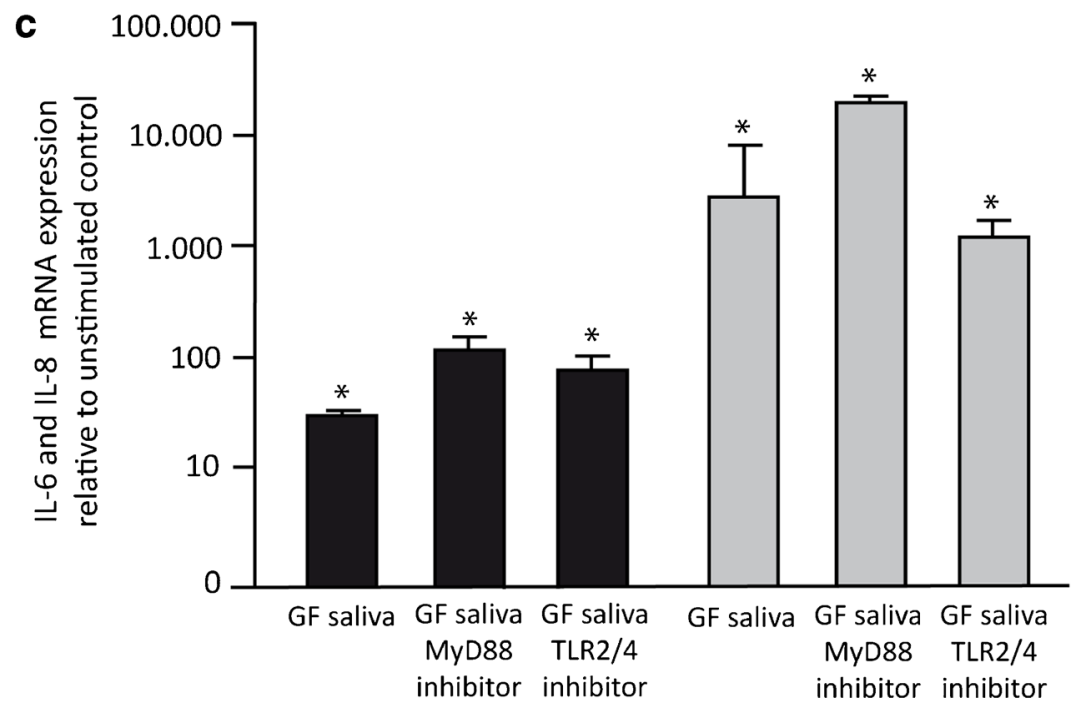

immediately after collection. For size exclusion chromatography of sterile-filtered whole saliva, Micro Bio-Spin 30 Columns (Bio-Rad Laboratories, Hercules, CA) were used. Heating of sterile-filtered whole saliva for $5 \mathrm{~min}$ at $96{ }^{\circ} \mathrm{C}$ was performed in a thermomixer (Eppendorf $\mathrm{AG}$, Hamburg, Germany). Freezing of sterile-filtered whole

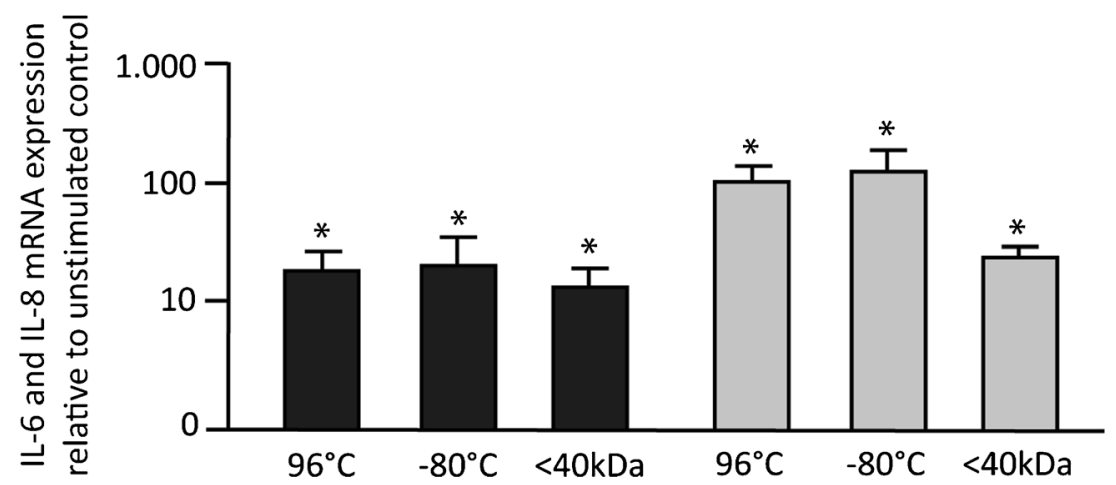

Fig. 3 Saliva after heating at $96^{\circ} \mathrm{C}$ maintains the ability to provoke IL-6 and IL- 8 expression. Different saliva treatment methods were performed in order to restrict the pro-inflammatory component. Sterile-filtered whole saliva, however, maintained the capacity to provoke IL-6 (black bars) and IL-8 (gray bars) expression by human gingiva fibroblasts when heated to $96^{\circ} \mathrm{C}$. Freezing as well as a molecular weight fraction obtained with a cutoff of $40 \mathrm{kDa}$ increased IL- 6 and IL- 8 expression in oral fibroblasts. A significant difference to unstimulated control was defined to be $p<0.05(* p<0.05)$ 


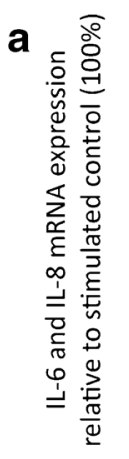

1.000
100
10
0

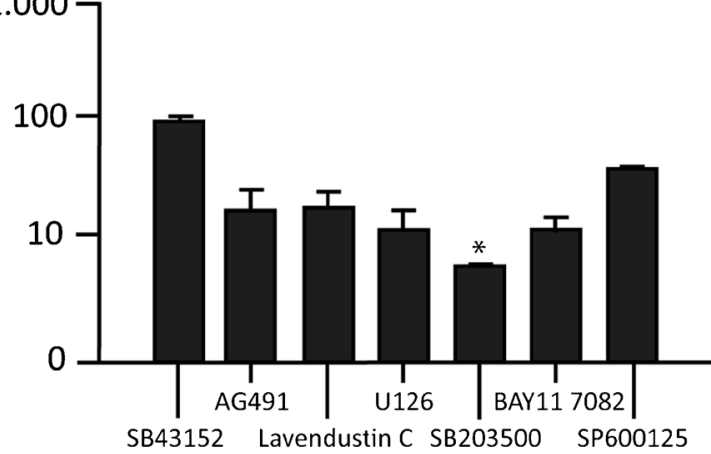

Fig. 4 Saliva-induced IL- 6 and IL-8 require MAPK, but not TGF- $\beta$ receptor I kinase or EGF receptor signaling. SB431542, the TGF- $\beta$ receptor I kinase inhibitor, AG-494 and Lavendustin C, both inhibitors of EGF receptor kinase, did not significantly change the expression pattern of IL-6 (black bars) and IL-8 (gray bars) in human gingiva fibroblasts. Inhibitors of the MAPK family and NFKB like U0126, b

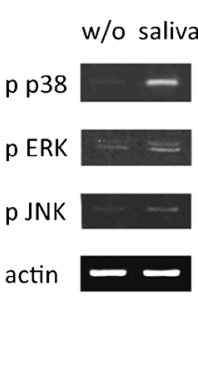

BAY 11-7082, and SB203580 reduced the expression of IL-6 and IL-8 in the presence of saliva. Interestingly, SP600125 enhanced the expression of IL-6 and IL-8 (a). Moreover, saliva increased phosphorylation of ERK, p38, and JNK in gingiva fibroblasts as shown in Western blot analysis (b). A significant difference to stimulated control was defined to be $p<0.05\left({ }^{*} p<0.05\right)$

Gene expression analysis

saliva was performed at $-80{ }^{\circ} \mathrm{C}$ for $24 \mathrm{~h}$. Cells were stimulated at a 10 -fold dilution immediately after preparation of the saliva.

Stimulation of cells with saliva and pathway inhibitors

Human gingiva fibroblasts were also exposed to inhibitors of mitogen-activated protein kinase (MAPK) signaling, e.g., U0126, SB203580, and SP600125, all at $10 \mu \mathrm{M}$ (Santa Cruz Biotechnology, SCBT; Santa Cruz, CA) in serum-free medium. Cyclooxygenase (COX) 1 and 2 were blocked with indomethacin at $1 \mu \mathrm{M}$ (Sigma). BAY 117082 was used to block nuclear factor-kappaB (NFkB) signaling at $10 \mu \mathrm{M}$. Inhibitors of epidermal growth factor (EGF) receptor kinase were $\mathrm{AG}-494$ at $10 \mu \mathrm{M}$ and lavendustin $\mathrm{C}$ at $10 \mu \mathrm{M}$ (all Enzo Life Sciences, Inc., Farmingdale, NY). SB431542, a TGF- $\beta$ receptor I kinase inhibitor was used at $10 \mu \mathrm{M}$ (SCBT).

\section{Gene chip analysis}

Total cellular RNA from human gingiva fibroblasts was isolated with the High Pure RNA Isolation Kit (Roche F. Hoffmann-La Roche, Basel Switzerland). Quality control of the RNAs, as well as labeling, hybridization, and scanning of the hybridized arrays, was performed by arrows biomedical Deutschland $\mathrm{GmbH}$ (Münster, Germany) using the Human GE $4 \times 44 \mathrm{~K}$ V2 Microarray Kit with SurePrint Technology (Agilent, Santa Clara, CA, USA).

Reverse transcription (RT) was performed with Transcriptor Universal cDNA Master (Roche), and polymerase chain reaction (PCR) was done with the FastStart Universal SYBR Green Master (Roche) on a 7500 Real-Time PCR System (Applied Biosystems, Life Technologies Corporation, Carlsbad, CA). Primers were designed in the online Universal ProbeLibrary Assay Design Center (Roche), and sequence is provided in Table 1. The messenger RNA (mRNA) levels were calculated by normalizing to GAPDH using the $\Delta \mathrm{Ct}$ method. The immunoassay for human IL-6 and IL-8 was obtained from Enzo Life Sciences and PeproTech GmbH (Hamburg, Germany), respectively.

Protein expression analysis by Luminex and immunoassay

Luminex analysis was performed by ProcartaPlex ${ }^{\mathrm{TM}}$ Multiplex Immunoassay (eBioscience Vienna, Austria) for human IL-6, human IL-8, human granulocyte-macrophage colonystimulating factor (GM-CSF), human growth regulated oncogene (GRO)-alpha, human monocyte chemotactic protein (MCP)-3, and human macrophage inflammatory protein (MIP)-3alpha. The immunoassay for human IL-6 and IL-8 was obtained from Enzo Life Sciences and PeproTech $\mathrm{GmbH}$ (Hamburg, Germany), respectively.

Western blot analysis

Human gingiva fibroblasts were serum-starved for overnight and then treated with freshly prepared sterile-filtered whole saliva immediately after saliva collection at the 10 -fold 
Table 3 Saliva induced substantial changes in other inflammatory genes as shown in a microarray. Experiment 1: gingiva fibroblasts with and without sterile-filtered whole saliva (1:10), $6 \mathrm{~h}$

\begin{tabular}{|c|c|c|c|c|c|}
\hline Probeset ID & Gene name & $\begin{array}{l}\text { Log intensity } \\
\text { (GF wo) }\end{array}$ & $\begin{array}{l}\text { Log intensity } \\
\text { (GF saliva) }\end{array}$ & Ratio & $\begin{array}{l}\text { Absolute } \\
\text { fold change }\end{array}$ \\
\hline A_32_P87013 & IL8 & 2.58899 & 15.2936 & 0.000149807 & 6675.27 \\
\hline A_23_P7144 & CXCL1 & 5.72941 & 17.4016 & 0.000306423 & 3263.47 \\
\hline A_23_P92107 & SLC15A2 & 13.2984 & 3.51625 & 880.482 & 880.482 \\
\hline A_23_P71037 & IL6 & 7.48191 & 17.1568 & 0.0012234 & 817.395 \\
\hline A_23_P17065 & CCL20 & 2.31199 & 11.9564 & 0.00124952 & 800.307 \\
\hline A_33_P3395422 & XM_001720080 & 2.49852 & 11.5931 & 0.00182919 & 546.69 \\
\hline A_24_P250922 & PTGS2 & 4.24932 & 13.2267 & 0.00198399 & 504.035 \\
\hline A_23_P152002 & BCL2A1 & 3.87836 & 12.8247 & 0.00202714 & 493.306 \\
\hline A_33_P3330264 & CXCL1 & 5.78246 & 14.7101 & 0.00205358 & 486.953 \\
\hline A_23_P340019 & NLRC3 & 12.062 & 3.44555 & 392.473 & 392.473 \\
\hline A_23_P153320 & ICAM1 & 5.39503 & 13.9985 & 0.00257097 & 388.958 \\
\hline A_23_P315364 & CXCL2 & 6.32403 & 14.8663 & 0.00268238 & 372.803 \\
\hline A_23_P55632 & SERPINB3 & 2.97668 & 11.3418 & 0.00303283 & 329.725 \\
\hline A_24_P257416 & CXCL2 & 6.14868 & 14.2923 & 0.00353611 & 282.796 \\
\hline A_24_P183150 & CXCL3 & 4.72527 & 12.8097 & 0.00368421 & 271.429 \\
\hline A_23_P133408 & CSF2 & 2.59006 & 10.6121 & 0.00384703 & 259.941 \\
\hline A_33_P3278279 & TXNDC8 & 2.83172 & 10.6824 & 0.00433221 & 230.829 \\
\hline A_33_P3243230 & ENST00000401931 & 2.70622 & 10.5018 & 0.00450087 & 222.179 \\
\hline A_33_P3447304 & OXR1 & 15.9867 & 8.2525 & 212.925 & 212.925 \\
\hline A_23_P78037 & CCL7 & 2.96843 & 10.5768 & 0.00512451 & 195.141 \\
\hline A_33_P3334798 & ANTXRL & 2.83134 & 10.3628 & 0.00540511 & 185.01 \\
\hline A_24_P303091 & CXCL10 & 2.50982 & 9.94392 & 0.00578246 & 172.937 \\
\hline A_23_P121676 & CXXC4 & 2.68255 & 9.9863 & 0.00632925 & 157.997 \\
\hline A_33_P3718269 & ENST00000517927 & 2.45629 & 9.71179 & 0.00654451 & 152.8 \\
\hline A_33_P3319791 & NR4A1 & 2.59948 & 9.82877 & 0.00666449 & 150.049 \\
\hline A_23_P398566 & NR4A3 & 6.37319 & 13.5613 & 0.00685746 & 145.827 \\
\hline A_33_P3343175 & CXCL10 & 2.62246 & 9.80532 & 0.00688246 & 145.297 \\
\hline A_32_P8546 & C6orf176 & 2.86401 & 9.98688 & 0.00717468 & 139.379 \\
\hline A_33_P3394559 & PRAMEF6 & 2.69292 & 9.7646 & 0.00743382 & 134.52 \\
\hline A_23_P104819 & TREH & 3.07481 & 10.0711 & 0.00783261 & 127.671 \\
\hline A_33_P3327106 & LOC100129900 & 2.74187 & 9.6895 & 0.0081013 & 123.437 \\
\hline A_23_P26024 & C15orf48 & 6.05466 & 12.9827 & 0.00821206 & 121.772 \\
\hline A_23_P79518 & IL1B & 3.16344 & 10.0609 & 0.00838799 & 119.218 \\
\hline A_24_P98006 & MCHR2 & 3.5985 & 10.493 & 0.00840521 & 118.974 \\
\hline A_23_P314755 & STC1 & 4.64903 & 11.5271 & 0.00850148 & 117.627 \\
\hline A_33_P3407013 & ENST00000420258 & 2.79436 & 9.53102 & 0.00937698 & 106.644 \\
\hline A_23_P216118 & UNC5D & 2.70118 & 9.27273 & 0.010514 & 95.1116 \\
\hline A_24_P63380 & BMPR1B & 3.16638 & 9.68382 & 0.0109158 & 91.6104 \\
\hline A_24_P237270 & ADORA2A & 2.50244 & 9.00375 & 0.0110385 & 90.5919 \\
\hline A_23_P155786 & SULT1E1 & 2.85388 & 9.3288 & 0.0112423 & 88.9499 \\
\hline A_23_P25155 & GPR84 & 2.44536 & 8.79923 & 0.0122263 & 81.791 \\
\hline A_33_P3265129 & ACSM2A & 2.8229 & 9.13686 & 0.0125692 & 79.5594 \\
\hline A_23_P89431 & CCL2 & 10.8917 & 17.1389 & 0.0131645 & 75.9617 \\
\hline A_23_P155755 & CXCL6 & 2.54966 & 8.77347 & 0.0133797 & 74.7401 \\
\hline A_23_P86470 & $\mathrm{CH} 25 \mathrm{H}$ & 6.81034 & 12.9794 & 0.0138972 & 71.9568 \\
\hline
\end{tabular}


Table 3 (continued)

\begin{tabular}{lllll}
\hline Probeset ID & Gene name & $\begin{array}{l}\text { Log intensity } \\
\text { (GF wo) }\end{array}$ & $\begin{array}{l}\text { Log intensity } \\
\text { (GF saliva) }\end{array}$ & $\begin{array}{l}\text { Ratio } \\
\text { Absolute } \\
\text { fold change }\end{array}$ \\
\hline A_33_P3313899 & LOC728228 & 3.0997 & 9.21134 & 6.0144615 \\
A_23_P420863 & NOD2 & 2.77057 & 8.87364 & 0.0145477 \\
A_23_P64828 & OAS1 & 3.52295 & 9.58639 & 0.0149528 \\
A_33_P3216758 & CEACAM16 & 3.84972 & 9.89933 & 0.0150968 \\
A_23_P353048 & SSPO & 2.566 & 8.57327 & 6.0155465 \\
\hline
\end{tabular}

This table shows the top 50 regulated genes, sorted by their absolute fold change. A fold change of, e.g., 2 indicates that the gene is 2 -fold upregulated in the GF wo vs GF saliva sample

dilution for $30 \mathrm{~min}$. Cell extracts containing sodium dodecyl sulfate (SDS) buffer and protease inhibitors (SCBT) were separated by SDS-PAGE and transferred onto nitrocellulose membranes (Whatman, GE Healthcare, General Electric Company, Fairfield, CT). Membranes were blocked in a supplied buffer (LI-COR Biosciences; Lincoln, NE). Binding of the antibody raised against phospho-p38, phospho-c-Jun Nterminal kinase (JNK) (both from Cell Signaling Technology, Danvers, MA), phospho-extracellular signal-regulated kinase (ERK), and $\beta$-actin (both SCBT). Primary antibodies were detected with the appropriate secondary antibody directly labeled with near-infrared dyes and detected with the appropriate imaging system (LI-COR Biosciences; Lincoln, NE).

Statistical analysis

Data represent the mean plus standard deviation of three independent experiments, each performed in triplicates. Differences in mRNA expression of target genes between stimulated and unstimulated cells were tested using a nonparametric Mann-Whitney $U$ test for paired samples (SPSS version 19.0, SPSS Inc., Chicago, IL, USA). Alpha of $5 \%$ was considered significant.

\section{Results}

Sterile-filtered whole saliva stimulates IL-6 and IL-8 in various cell types of the oral cavity

As shown in Fig. 1a, all fibroblastic cells, independent of their origin, showed a significant response to saliva as indicated by the $>10$-fold increase in the expression of IL- 6 and IL- $8(p<0.05)$. The monocytic cell line and both epithelial cells, however, showed a rather moderate response with an increase in the two cytokines below 10 -fold (Fig. 1a) $(p>0.05)$. The response of the fibroblasts to saliva translates into protein as shown with
ELISA (Table 2) and Luminex technology using the culture supernatants (Table 2).

Freshly harvested sterile-filtered whole saliva increases mRNA of IL-6 and IL-8

Sterile-filtered whole saliva considerably ( $>10$-fold) increased the mRNA level of the IL- 6 and IL- $8(p<0.05)$. Dose-response curves indicate that the maximal stimulation was reached at a dilution factor of 10-fold (Fig. 1b). Time-response curves showed a substantial expression after $6 \mathrm{~h}$ (data not shown). Cell morphology was maintained in diluted saliva (Fig. 1c). Further experiments were thus performed with sterile-filtered whole saliva at the 10 -fold dilution and exposure time of $6 \mathrm{~h}$.

Bacteria and microorganism do not cause the inflammatory reaction

To preclude that the observed pro-inflammatory activity is the result of oral bacteria, we used sterile-filtered parotid saliva collected under almost aseptic conditions instead of sterile-filtered whole saliva. This sterilefiltered parotid saliva increased IL-6 and IL-8 expression in gingiva fibroblasts $(>10$-fold; Fig. $2 a)(p<0.05)$. The number of colonies was less than $10^{2} / \mathrm{ml}$ (from approximately 5 to $75 \mathrm{CFU} / \mathrm{ml}$ ) (Fig. 2b), and a second blood agar plate and the lysogeny broth agar plates showed one single colony or no colonies, respectively (data not shown). Bacterial toxins are unlikely to be responsible for the inflammatory reaction under these conditions.

Sterile-filtered whole saliva also significantly $(p<0.05)$ increased the mRNA level of the IL- 6 and IL- 8 in the case when MYD88 and Toll-like receptors 2 and 4, respectively, were blocked, which is a supplementary proof that the effect is 
Table 4 Saliva induced substantial changes in other inflammatory genes as shown in a microarray. Experiment 2: gingiva fibroblasts with and without sterile-filtered whole saliva (1:10), $6 \mathrm{~h}$

\begin{tabular}{|c|c|c|c|c|c|}
\hline Probeset ID & Gene name & $\begin{array}{l}\text { Log intensity } \\
\text { (GF wo) }\end{array}$ & $\begin{array}{l}\text { Log intensity } \\
\text { (GF saliva) }\end{array}$ & Ratio & $\begin{array}{l}\text { Absolute } \\
\text { fold change }\end{array}$ \\
\hline A_23_P7144 & CXCL1 & 3.14235 & 16.267 & 0.00011197 & 8931.27 \\
\hline A_32_P87013 & IL8 & 3.21679 & 14.8875 & 0.00030674 & 3260.12 \\
\hline A_23_P133408 & CSF2 & 3.19471 & 12.1627 & 0.00199694 & 500.765 \\
\hline A_23_P315364 & CXCL2 & 5.01458 & 13.7903 & 0.00228163 & 438.284 \\
\hline A_24_P183150 & CXCL3 & 3.43033 & 12.0855 & 0.00248047 & 403.149 \\
\hline A_23_P71037 & IL6 & 6.70614 & 15.2084 & 0.00275781 & 362.606 \\
\hline A_23_P153320 & ICAM1 & 5.73492 & 13.6422 & 0.00416554 & 240.065 \\
\hline A_23_P152002 & BCL2A1 & 4.56323 & 12.0878 & 0.00543099 & 184.129 \\
\hline A_24_P250922 & PTGS2 & 4.06508 & 11.5464 & 0.00559627 & 178.691 \\
\hline A_33_P3243230 & ENST00000401931 & 3.31141 & 10.3956 & 0.00736964 & 135.692 \\
\hline A_23_P17065 & CCL20 & 3.02568 & 9.96244 & 0.00816258 & 122.51 \\
\hline A_32_P83270 & LOC727982 & 5.47545 & 12.4016 & 0.00822283 & 121.613 \\
\hline A_33_P3329133 & A_33_P3329133 & 10.3814 & 3.54916 & 113.949 & 113.949 \\
\hline A_33_P3330264 & CXCL1 & 6.82458 & 13.3723 & 0.0106891 & 93.5535 \\
\hline A_33_P3232692 & IL24 & 4.0788 & 10.5369 & 0.0113741 & 87.9188 \\
\hline A_23_P144843 & ESM1 & 3.34632 & 9.67079 & 0.012478 & 80.1411 \\
\hline A_33_P3308142 & GPCRLTM7 & 9.66042 & 3.34008 & 79.912 & 79.912 \\
\hline A_24_P257416 & CXCL2 & 6.9368 & 13.1254 & 0.0137103 & 72.938 \\
\hline A_23_P89431 & CCL2 & 8.9014 & 15.0877 & 0.0137321 & 72.8219 \\
\hline A_23_P79518 & IL1B & 4.01301 & 10.1022 & 0.0146883 & 68.0814 \\
\hline A_23_P314755 & STC1 & 4.43322 & 10.4882 & 0.0150407 & 66.4861 \\
\hline A_33_P3718269 & ENST00000517927 & 3.12341 & 9.00892 & 0.0169155 & 59.1174 \\
\hline A_33_P3353372 & ENST00000430825 & 3.40559 & 9.14634 & 0.0187009 & 53.4734 \\
\hline A_24_P247536 & FAM133B & 3.51247 & 9.16346 & 0.0199014 & 50.2478 \\
\hline A_33_P3374987 & C7orf52 & 9.10426 & 3.53162 & 47.5918 & 47.5918 \\
\hline A_33_P3381821 & CAPN14 & 9.8493 & 4.30557 & 46.6476 & 46.6476 \\
\hline A_33_P3341269 & A_33_P3341269 & 9.70211 & 4.22435 & 44.5626 & 44.5626 \\
\hline A_33_P3362826 & ANKRD31 & 8.92233 & 3.48238 & 43.4098 & 43.4098 \\
\hline A_33_P3219095 & LOC728606 & 9.83125 & 4.61898 & 37.0723 & 37.0723 \\
\hline A_23_P904 & BEND5 & 8.82691 & 3.62997 & 36.6805 & 36.6805 \\
\hline A_24_P237270 & ADORA2A & 3.15832 & 8.31359 & 0.0280614 & 35.6362 \\
\hline A_24_P558750 & LOC100132963 & 8.6176 & 3.49169 & 34.9183 & 34.9183 \\
\hline A_24_P122137 & LIF & 8.44265 & 13.5675 & 0.0286594 & 34.8926 \\
\hline A_32_P182299 & C1orf168 & 8.45535 & 3.38041 & 33.7062 & 33.7062 \\
\hline A_23_P164100 & C17orf64 & 9.85009 & 4.81162 & 32.8648 & 32.8648 \\
\hline A_33_P3261862 & OR2A1 & 11.9851 & 6.96219 & 32.5122 & 32.5122 \\
\hline A_23_P26024 & C15orf48 & 6.60795 & 11.5287 & 0.0330147 & 30.2896 \\
\hline A_33_P3363355 & ICAM4 & 5.24671 & 10.0793 & 0.035095 & 28.4941 \\
\hline A_23_P10206 & HAS2 & 5.58408 & 10.3984 & 0.0355423 & 28.1355 \\
\hline A_23_P78037 & CCL7 & 4.81524 & 9.616 & 0.0358779 & 27.8723 \\
\hline A_33_P3387971 & ENST00000457336 & 9.48331 & 4.76869 & 26.2568 & 26.2568 \\
\hline A_33_P3293456 & GATA4 & 10.3526 & 5.65175 & 26.0074 & 26.0074 \\
\hline A_23_P30163 & FLJ13197 & 9.90088 & 5.2655 & 24.8535 & 24.8535 \\
\hline A_23_P398566 & NR4A3 & 7.38279 & 11.965 & 0.0417462 & 23.9543 \\
\hline A_24_P362595 & PAX3 & 8.22594 & 3.66421 & 23.6166 & 23.6166 \\
\hline
\end{tabular}


Table 4 (continued)

\begin{tabular}{lllcc}
\hline Probeset ID & Gene name & $\begin{array}{l}\text { Log intensity } \\
\text { (GF wo) }\end{array}$ & $\begin{array}{l}\text { Log intensity } \\
\text { (GF saliva) }\end{array}$ & $\begin{array}{l}\text { Ratio } \\
\text { fold change }\end{array}$ \\
\hline A_33_P3312519 & KPRP & 4.89513 & 9.44004 & 0.0428397 \\
A_33_P3237150 & BMP2 & 6.51219 & 10.9824 & 0.0451162 \\
A_33_P3309456 & DNAH8 & 8.07288 & 3.61994 & 21.9012 \\
A_33_P3319791 & NR4A1 & 3.23374 & 7.68543 & 0.0456991 \\
A_23_P13753 & NFE2 & 7.95151 & 3.52037 & 21.5728 \\
\hline
\end{tabular}

This table shows the top 50 regulated genes, sorted by their absolute fold change. A fold change of, e.g., 2 indicates that the gene is 2 -fold upregulated in the GF wo vs GF saliva sample

caused by the saliva and not by microorganism or their products (Fig. 2c).

Saliva after heating at $96{ }^{\circ} \mathrm{C}$ maintains the ability to provoke IL-6 and IL-8 expression

Saliva when heated to $96{ }^{\circ} \mathrm{C}$ maintained the capacity to provoke IL-6 and IL-8 expression by gingiva fibroblasts. Freezing preserved the pro-inflammatory activity of saliva. A molecular weight fraction obtained with a cutoff of $40 \mathrm{kDa}$ increased IL-6 and IL-8 expression (Fig. 3). All saliva treatment methods indicated the same results - an increase of IL- 6 and IL- 8 expression in oral fibroblasts $(p<0.05)$.

Saliva-induced IL-6 and IL-8 require NFKB and MAPK signaling

U0126, BAY 11-7082, and SB203580 reduced the expression of IL- 6 and IL-8 in the presence of saliva (Fig. 4a). Interestingly, SP600125 enhanced the expression of IL-6 and IL-8 in this setting. SB431542, the TGF- $\beta$ receptor I kinase inhibitor, AG-494, and Lavendustin C, both inhibitors of EGF receptor kinase, did not significantly influence the expression pattern of IL-6 and IL-8 in gingiva fibroblasts (Fig. 4a). In line with these data, saliva increased phosphorylation of ERK, JNK, and p38 in gingiva fibroblasts (Fig. 4b). As the ERK involvement is lacking in LPS-stimulated IL-6 in fibroblasts [27], this is a further indication that microorganisms are not involved.

Saliva induced substantial changes in other inflammatory genes and proteins

To rule out that the observed changes are restricted to the two inflammatory cytokines, a screening approach with a microarray (Tables 3, 4, 5, and 6) and a Luminex analysis were performed. RT-PCR confirmed that saliva caused a substantial increase of the selected genes, e.g., ICAM-1, CXCL1,
CXCL2, CXCL3, CXCL6, CCL7, CCL20, CSF 2, SERPIN B3, PTGS2, and BCL2A1 (Fig. 5). Cytokines examined using the Luminex technology also showed an increase in fibroblasts treated with saliva (Table 2).

\section{Discussion}

Saliva has beneficial effects on wound healing in preclinical studies [6,7], and wound healing requires an early inflammatory response [15]. It was thus reasonable to suggest that saliva causes its beneficial effect on wound healing by supporting the inflammatory reaction. However, the in vitro data linking saliva, its components, and the inflammatory response in vitro are not entirely consistent $[9,10]$. We now report that saliva initiates a massive proinflammatory reaction of oral fibroblasts, but not in epithelial cells. These results are indicated by a strong increase in the expression of the "indicator cytokines" IL-6, IL-8, and a panel of other inflammatory mediators. Moreover, we provide insights into the cellular mechanisms involving $\mathrm{NFKB}$ and MAPK signaling and show that saliva can be heated up to $96{ }^{\circ} \mathrm{C}$ and size fractionated but still maintaining the pro-inflammatory activity. These data add another piece of knowledge to the large spectrum of biologic function of saliva. Even though the clinical relevance remains a matter of speculation, there is good reason to assume that saliva can provoke an inflammatory response in the oral connective tissue, when contact occurs through an injury of the epithelial layer.

If we relate our findings to those of others, two studies are particularly relevant: those of Proksch et al. [9] and Komine et al. [10]. In the first study [9], murine osteogenic MC3T3-E1 cells showed a slight but no significant inflammatory response to saliva, which is in contrast to the sharp increase of IL- 6 and IL- 8 in our in vitro system. These discrepancies can have multiple reasons including the species differences, the lyophilization process, the use of different types of cells, and different stimulation times 
Table 5 Saliva induced substantial changes in other inflammatory genes as shown in a microarray. GO enrichment analysis: experiment 1

\begin{tabular}{|c|c|c|c|c|c|c|c|}
\hline Function & Type & $\begin{array}{l}\text { Enrichment } \\
\text { score }\end{array}$ & $\begin{array}{l}\text { Enrichment } \\
p \text { value }\end{array}$ & $\begin{array}{l}\% \text { Genes in } \\
\text { group that are } \\
\text { present }\end{array}$ & $\begin{array}{l}\text { \# Genes in } \\
\text { list, in group }\end{array}$ & $\begin{array}{l}\text { \# Genes not } \\
\text { in list, in group }\end{array}$ & GO ID \\
\hline Inflammatory response & Biological process & 37.583 & $4.76 \mathrm{E}-17$ & 32.526 & 94 & 195 & 6,954 \\
\hline Extracellular space & Cellular component & 33.5596 & $2.66 \mathrm{E}-15$ & 23.3173 & 194 & 638 & 5,615 \\
\hline Response to virus & Biological process & 31.1282 & $3.03 \mathrm{E}-14$ & 42.4779 & 48 & 65 & 9,615 \\
\hline Cell-cell signaling & Biological process & 25.6075 & $7.57 \mathrm{E}-12$ & 30.2905 & 73 & 168 & 7,267 \\
\hline $\begin{array}{l}\text { Positive regulation of transcription } \\
\text { from RNA polymerase II } \\
\text { promoter }\end{array}$ & Biological process & 25.5894 & $7.70 \mathrm{E}-12$ & 22.7994 & 158 & 535 & 45,944 \\
\hline Plasma membrane & Cellular component & 24.1036 & $3.40 \mathrm{E}-11$ & 16.9154 & 612 & 3,006 & 5,886 \\
\hline Chemokine activity & Molecular function & 23.6638 & $5.28 \mathrm{E}-11$ & 53.0612 & 26 & 23 & 8,009 \\
\hline Signal transduction & Biological process & 23.327 & $7.40 \mathrm{E}-11$ & 20.412 & 218 & 850 & 7,165 \\
\hline Response to lipopolysaccharide & Biological process & 20.7765 & $9.48 \mathrm{E}-10$ & 34.3511 & 45 & 86 & 32,496 \\
\hline Cytokine-mediated signaling pathway & Biological process & 20.0092 & $2.04 \mathrm{E}-09$ & 28.7671 & 63 & 156 & 19,221 \\
\hline Cytokine activity & Molecular function & 19.3653 & $3.89 \mathrm{E}-09$ & 31.0976 & 51 & 113 & 5,125 \\
\hline $\begin{array}{l}\text { Type I interferon-mediated signaling } \\
\text { pathway }\end{array}$ & Biological process & 19.1956 & $4.61 \mathrm{E}-09$ & 43.0769 & 28 & 37 & 60,337 \\
\hline Growth factor activity & Molecular function & 18.906 & $6.15 \mathrm{E}-09$ & 30.7229 & 51 & 115 & 8,083 \\
\hline Defense response to virus & Biological process & 17.5171 & $2.47 \mathrm{E}-08$ & 31.6547 & 44 & 95 & 51,607 \\
\hline Integral to plasma membrane & Cellular component & 17.3154 & $3.02 \mathrm{E}-08$ & 19.4015 & 201 & 835 & 5,887 \\
\hline Angiogenesis & Biological process & 16.1778 & $9.42 \mathrm{E}-08$ & 27.6382 & 55 & 144 & 1,525 \\
\hline $\begin{array}{l}\text { Positive regulation of endothelial cell } \\
\text { proliferation }\end{array}$ & Biological process & 15.7807 & $1.40 \mathrm{E}-07$ & 42.5926 & 23 & 31 & 1,938 \\
\hline $\begin{array}{l}\text { Positive regulation of epithelial cell } \\
\text { proliferation }\end{array}$ & Biological process & 15.7807 & $1.40 \mathrm{E}-07$ & 42.5926 & 23 & 31 & 50,679 \\
\hline $\begin{array}{l}\text { Negative regulation of viral genome } \\
\text { replication }\end{array}$ & Biological process & 15.0232 & $2.99 \mathrm{E}-07$ & 55.5556 & 15 & 12 & 45,071 \\
\hline $\begin{array}{l}\text { Positive regulation of smooth muscle } \\
\text { cell proliferation }\end{array}$ & Biological process & 14.8828 & $3.44 \mathrm{E}-07$ & 46.3415 & 19 & 22 & 48,661 \\
\hline Chemotaxis & Biological process & 14.796 & $3.75 \mathrm{E}-07$ & 31.8584 & 36 & 77 & 6,935 \\
\hline $\begin{array}{l}\text { Positive regulation of ERK1 and } \\
\text { ERK2 cascade }\end{array}$ & Biological process & 14.4698 & $5.20 \mathrm{E}-07$ & 34.4828 & 30 & 57 & 70,374 \\
\hline Extracellular region & Cellular component & 13.55 & $1.30 \mathrm{E}-06$ & 17.3835 & 291 & 1,383 & 5,576 \\
\hline $\begin{array}{l}\text { Positive regulation of interleukin- } 6 \\
\text { production }\end{array}$ & Biological process & 13.5017 & $1.37 \mathrm{E}-06$ & 48.4848 & 16 & 17 & 32,755 \\
\hline Positive regulation of cell proliferation & Biological process & 13.2704 & $1.72 \mathrm{E}-06$ & 22 & 88 & 312 & 8,284 \\
\hline Inner ear morphogenesis & Biological process & 13.1364 & $1.97 \mathrm{E}-06$ & 38.5965 & 22 & 35 & 42,472 \\
\hline Lung alveolus development & Biological process & 12.9994 & $2.26 \mathrm{E}-06$ & 47.0588 & 16 & 18 & 48,286 \\
\hline Negative regulation of apoptotic process & Biological process & 12.9011 & $2.50 \mathrm{E}-06$ & 21.2719 & 97 & 359 & 43,066 \\
\hline Response to exogenous dsRNA & Biological process & 12.6915 & $3.08 \mathrm{E}-06$ & 66.6667 & 10 & 5 & 43,330 \\
\hline Toll-like receptor 4 signaling pathway & Biological process & 12.4329 & $3.99 \mathrm{E}-06$ & 33.3333 & 27 & 54 & 34,142 \\
\hline
\end{tabular}

The table shows the top $40 \mathrm{GO}$ functional groups sorted by their enrichment score after GO enrichment analysis with the 4,255 regulated genes. Cutoff: $\mathrm{FC}>2.0$ or $\mathrm{FC} \leq 2$

with salivary components or whole saliva, respectively. The second study [10] was based on saliva of periodontitis patients where lactoferrin was cleaved by protease-3, an enzyme typically released from neutrophil granulocytes. They also include saliva of the parotid gland. The truncated lactoferrin has a potent inflammatory activity for HSC-2 cell increasing IL-6 and IL-8 - which is in line with the present study. However, in our hands, whole saliva from healthy donors failed to cause a substantial increase of IL-6 and IL-8 in HSC-2 cells, suggesting that truncated lactoferrin can only partially explain the findings of the present study.

In our attempt to understand the signaling cascade that accounts responsible for the strong expression of IL-6 and IL-8, we have performed a traditional approach with pharmacologic inhibitors and detection of 
Table 6 Saliva induced substantial changes in other inflammatory genes as shown in a microarray. GO enrichment analysis: experiment 2

\begin{tabular}{|c|c|c|c|c|c|c|c|}
\hline Function & Type & $\begin{array}{l}\text { Enrichment } \\
\text { score }\end{array}$ & $\begin{array}{l}\text { Enrichment } \\
p \text { value }\end{array}$ & $\begin{array}{l}\% \text { Genes in } \\
\text { group that are } \\
\text { present }\end{array}$ & $\begin{array}{l}\text { \# Genes in } \\
\text { list, in group }\end{array}$ & $\begin{array}{l}\text { \# Genes not } \\
\text { in list, in } \\
\text { group }\end{array}$ & GO ID \\
\hline Plasma membrane & Cellular component & 26.2944 & $3.81 \mathrm{E}-12$ & 13.8474 & 501 & 3,117 & 5,886 \\
\hline Inflammatory response & Biological process & 25.6263 & $7.42 \mathrm{E}-12$ & 24.5675 & 71 & 218 & 6,954 \\
\hline Integral to plasma membrane & Cellular component & 23.8173 & $4.53 \mathrm{E}-11$ & 17.0849 & 177 & 859 & 5,887 \\
\hline Sequence-specific DNA binding & Molecular function & 22.8939 & $1.14 \mathrm{E}-10$ & 19.7417 & 107 & 435 & 43,565 \\
\hline Extracellular space & Cellular component & 22.314 & $2.04 \mathrm{E}-10$ & 17.6683 & 147 & 685 & 5,615 \\
\hline $\begin{array}{l}\text { Negative regulation of transcription from } \\
\text { RNA polymerase II promoter }\end{array}$ & Biological process & 18.7649 & $7.09 \mathrm{E}-09$ & 19.1837 & 94 & 396 & 122 \\
\hline $\begin{array}{l}\text { Positive regulation of transcription from } \\
\text { RNA polymerase II promoter }\end{array}$ & Biological process & 18.4929 & $9.30 \mathrm{E}-09$ & 17.6046 & 122 & 571 & 45,944 \\
\hline Cytokine activity & Molecular function & 15.9752 & $1.15 \mathrm{E}-07$ & 25 & 41 & 123 & 5,125 \\
\hline Angiogenesis & Biological process & 15.2185 & $2.46 \mathrm{E}-07$ & 23.1156 & 46 & 153 & 1,525 \\
\hline Extracellular region & Cellular component & 14.947 & $3.23 \mathrm{E}-07$ & 14.3369 & 240 & 1,434 & 5,576 \\
\hline Multicellular organismal development & Biological process & 14.8683 & $3.49 \mathrm{E}-07$ & 18.0698 & 88 & 399 & 7,275 \\
\hline Growth factor activity & Molecular function & 14.5784 & $4.66 \mathrm{E}-07$ & 24.0964 & 40 & 126 & 8,083 \\
\hline Cell-cell signaling & Biological process & 13.7973 & $1.02 \mathrm{E}-06$ & 21.1618 & 51 & 190 & 7,267 \\
\hline Signal transduction & Biological process & 13.6454 & $1.19 \mathrm{E}-06$ & 15.1685 & 162 & 906 & 7,165 \\
\hline $\begin{array}{l}\text { Sequence-specific DNA binding transcription } \\
\text { factor activity }\end{array}$ & Molecular function & 12.9735 & $2.32 \mathrm{E}-06$ & 15.3439 & 145 & 800 & 3,700 \\
\hline Chemotaxis & Biological process & 12.3066 & $4.52 \mathrm{E}-06$ & 25.6637 & 29 & 84 & 6,935 \\
\hline Negative regulation of growth & Biological process & 11.9435 & $6.50 \mathrm{E}-06$ & 52.6316 & 10 & 9 & 45,926 \\
\hline Positive regulation of apoptotic process & Biological process & 11.1806 & $1.39 \mathrm{E}-05$ & 20.7921 & 42 & 160 & 43,065 \\
\hline Positive regulation of gene expression & Biological process & 10.7139 & $2.22 \mathrm{E}-05$ & 23.7705 & 29 & 93 & 10,628 \\
\hline $\begin{array}{l}\text { RNA polymerase II core promoter proximal } \\
\text { region sequence-specific DNA binding } \\
\text { transcription factor activity involved in } \\
\text { positive regulation of transcription }\end{array}$ & Molecular function & 10.6509 & $2.37 \mathrm{E}-05$ & 30.5085 & 18 & 41 & 1,077 \\
\hline Chemokine activity & Molecular function & 10.5564 & $2.60 \mathrm{E}-05$ & 32.6531 & 16 & 33 & 8,009 \\
\hline Steroid hormone receptor activity & Molecular function & 10.2735 & $3.45 \mathrm{E}-05$ & 32 & 16 & 34 & 3,707 \\
\hline Integral to membrane & Cellular component & 10.0453 & $4.34 \mathrm{E}-05$ & 12.223 & 535 & 3,842 & 16,021 \\
\hline $\begin{array}{l}\text { Positive regulation of smooth muscle cell } \\
\text { proliferation }\end{array}$ & Biological process & 9.96277 & $4.71 \mathrm{E}-05$ & 34.1463 & 14 & 27 & 48,661 \\
\hline G-protein coupled receptor signaling pathway & Biological process & 9.92099 & $4.91 \mathrm{E}-05$ & 17.9245 & 57 & 261 & 7,186 \\
\hline Postsynaptic membrane & Cellular component & 9.73556 & $5.91 \mathrm{E}-05$ & 20.3209 & 38 & 149 & 45,211 \\
\hline Transcription regulatory region DNA binding & Molecular function & 9.66103 & $6.37 \mathrm{E}-05$ & 21.118 & 34 & 127 & 44,212 \\
\hline Macrophage chemotaxis & Biological process & 9.53532 & $7.23 \mathrm{E}-05$ & 58.3333 & 7 & 5 & 48,246 \\
\hline Negative regulation of apoptotic process & Biological process & 9.53232 & $7.25 \mathrm{E}-05$ & 16.4474 & 75 & 381 & 43,066 \\
\hline Palate development & Biological process & 9.45095 & $7.86 \mathrm{E}-05$ & 28.125 & 18 & 46 & 60,021 \\
\hline Positive regulation of leukocyte migration & Biological process & 9.33212 & $8.85 \mathrm{E}-05$ & 66.6667 & 6 & 3 & 2,687 \\
\hline Artery morphogenesis & Biological process & 9.2838 & $9.29 \mathrm{E}-05$ & 45 & 9 & 11 & 48,844 \\
\hline Negative regulation of ERK1 and ERK2 cascade & Biological process & 9.2838 & $9.29 \mathrm{E}-05$ & 45 & 9 & 11 & 70,373 \\
\hline $\begin{array}{l}\text { RNA polymerase II core promoter proximal } \\
\text { region sequence-specific DNA binding } \\
\text { transcription factor activity involved in } \\
\text { negative regulation of } \\
\text { transcription }\end{array}$ & Molecular function & 9.18031 & 0.00010305 & 37.931 & 11 & 18 & 1,078 \\
\hline $\begin{array}{l}\text { Termination of G-protein coupled receptor } \\
\text { signaling pathway }\end{array}$ & Biological process & 9.06133 & 0.00011607 & 33.3333 & 13 & 26 & 38,032 \\
\hline Protein dimerization activity & Molecular function & 8.94231 & 0.00013074 & 20.625 & 33 & 127 & 46,983 \\
\hline Cellular response to zinc ion & Biological process & 8.85821 & 0.00014221 & 53.8462 & 7 & 6 & 71,294 \\
\hline
\end{tabular}


Table 6 (continued)

\begin{tabular}{|c|c|c|c|c|c|c|c|}
\hline Function & Type & $\begin{array}{l}\text { Enrichment } \\
\text { score }\end{array}$ & $\begin{array}{l}\text { Enrichment } \\
p \text { value }\end{array}$ & $\begin{array}{l}\% \text { Genes in } \\
\text { group that are } \\
\text { present }\end{array}$ & $\begin{array}{l}\text { \# Genes in } \\
\text { list, in group }\end{array}$ & $\begin{array}{l}\text { \# Genes not } \\
\text { in list, in } \\
\text { group }\end{array}$ & GO ID \\
\hline Suckling behavior & Biological process & 8.85821 & 0.00014221 & 53.8462 & 7 & 6 & 1,967 \\
\hline Intracellular receptor mediated signaling pathway & Biological process & 8.8236 & 0.00014722 & 36.6667 & 11 & 19 & 30,522 \\
\hline Positive regulation of protein kinase activity & Biological process & 8.76945 & 0.00015541 & 32.5 & 13 & 27 & 45,860 \\
\hline
\end{tabular}

The table shows the top $40 \mathrm{GO}$ functional groups sorted by their enrichment score after GO enrichment analysis with the 3,569 regulated genes. Cutoff: $\mathrm{FC}>2.0$ or $\mathrm{FC} \leq 2$

phosphorylation signals of MAPK. Our findings that $\mathrm{NFKB}, \mathrm{p} 38$, and ERK signal pathways mediate the cellular response to increase IL- 6 and IL-8 expression are well documented for other in vitro settings. Interestingly, blocking of the TGF- $\beta$ receptor I kinase or EGF receptor kinase did not change the pro-inflammatory response to saliva. TGF- $\beta$ is present in saliva and can stimulate IL-6 and IL-8 expression in vitro-however, the impact of recombinant TGF- $\beta$ is substantially less pronounced than we have observed with saliva. Even though TGF- $\beta$ and EGF are present in saliva and the receptor can mediate IL6 and IL-8 expression [28], in our study, blocking of TGF- $\beta$ receptor I kinase or EGF receptor kinase had no such an effect. Moreover, indomethacin failed to change IL-6 and IL-8 expression, indicating that cyclooxygenasedependent lipid metabolites are not required for this cellular reaction. Together, the data suggest that the classical NFKB, p38, and ERK signal pathways mediate the proinflammatory reaction of oral fibroblasts to saliva in vitro.

The question arises if salivary bacteria and their products make the stimulation of inflammatory cytokines by fibroblasts and a reduced induction in epithelial cells expected. We therefore harvested saliva from the stimulated parotid gland under aseptic conditions. This freshly prepared parotid saliva also enhanced the IL-6 and IL-8 expression in gingiva fibroblasts and, importantly, only showed low bacterial counts when grown on blood and LB agar, in contrast to whole saliva which contains a high bacterial load. However, we need to specify that the expression of IL- 6 and IL-8 in gingiva fibroblasts was lower when stimulated with parotid saliva than with sterilefiltered whole saliva. This, together with the fact that sterilefiltered whole saliva heated up to $96^{\circ} \mathrm{C}$ maintains the strong pro-inflammatory effect, does not exclude the participation of microorganisms and their products. Otherwise parotid saliva still showed a more than 10 -fold significant increase in inflammatory genes, and further experiments with sterilefiltered whole saliva showed that the inflammatory response was independent of MYD88, and Toll-like receptors 4 and 2, respectively, which are central to the signaling of lipoteichoic acid and lipopolysaccharides [29]. Therefore, we assume that microorganisms did not cause the strong pro-inflammatory effects in this in vitro study. However, saliva might still

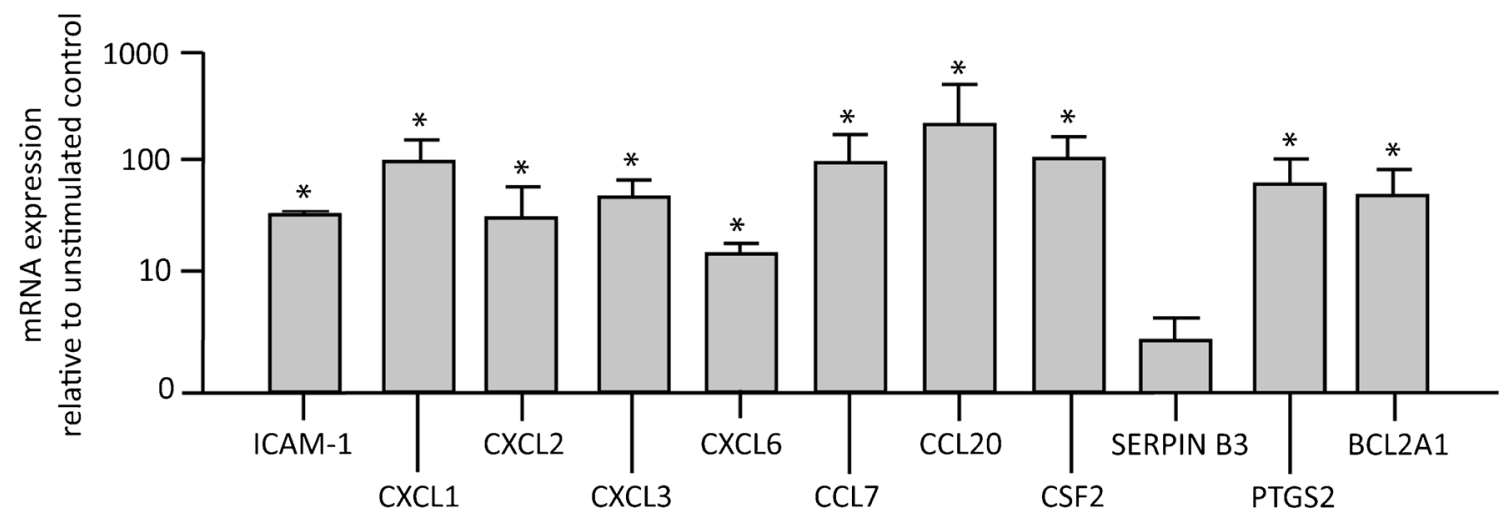

Fig. 5 Saliva induced substantial changes in other inflammatory genes and proteins. The whole genome array revealed genes that were strongly expressed when human gingiva fibroblasts were exposed to saliva. RTPCR partially confirmed these data; the most striking was the increase of

the selected genes, e.g., ICAM-1, CXCL1, CXCL2, CXCL3, CXCL6, CCL7, CCL20, CSF 2, SERPIN B3, PTGS2, and BCL2A1. A significant difference to unstimulated control was defined to be $p<0.05\left({ }^{*} p<0.05\right)$. 
contain microorganisms and bacterial components below the detection limit for the period of investigation used in our study.

We have also tried to understand what components of saliva are responsible for the pro-inflammatory reaction of oral fibroblasts. For example, boiling was performed on histatin 5 to reveal the impact of proteases in saliva [30]. Importantly, whole saliva contains a unique mixture of proteolytic enzymes that are even resistant to protease inhibitor cocktails [30]. Thus, in line with our protocol, freshly prepared saliva should be preferred over frozen samples for in vitro research. In the present study, saliva heat-treated for $95{ }^{\circ} \mathrm{C}$ for $5 \min$ [31] maintained the capacity to boost IL- 6 and IL- 8 expression in the oral fibroblasts. Heat-stable preparations from bacteria that activate pattern recognition receptors can cause a proinflammatory cell response [32]; however, the bacterial load of freshly prepared saliva immediately filtered sterile is improbable. Size fractionation showed data that a proinflammatory activity is present within the $<40-\mathrm{kDa}$ fraction. This is, however, only a first step for characterization, as it is known that more than $60 \%$ of the saliva proteins have a molecular weight less than $60 \mathrm{kDa}[33$, 34]. Our data are in line with the findings that saliva lactoferrin cleaved peptides, all showing less than $60 \mathrm{kDa}$, possesses inflammatory properties [10]. However, whole saliva is complex, and it requires further studies to understand if our finding can be attributed to saliva lactoferrin cleaved peptides alone.

The present study has opened the door for future research. At the saliva level, we would like to further characterize what component(s) in saliva are responsible for the strong inflammatory response of oral fibroblasts. At the level of oral fibroblasts, we will further advance the preliminary data obtained with the whole genome-wide microarray. By this screening approach, the full complexity of the strong cellular response to saliva becomes obvious. Moreover, fibroblast from other sources such as the dental pulp or cells involved in inflammation or tissue repair should be tested for their response to saliva. The key question, however, remains open, namely the clinical relevance of our findings - does saliva indeed cause a local inflammatory response upon contact with fibroblasts when epithelial layer is interrupted on wound site? If so, does this reaction help the innate immune system to support wound healing? We close the discussion with these challenging questions.

In summary, we conclude that freshly harvested sterilefiltered saliva can provoke a strong inflammatory response of oral fibroblasts, but not in epithelial cells in vitro. These in vitro findings may serve as a base for further in vitro investigations and following preclinical and clinical studies aiming at inflammatory response and even regeneration of oral fibroblasts in regenerative dentistry.
Acknowledgments We thank Catherine Solioz for skillful technique assistance and Fumie Saji for sharing her research experience with us. We also thank Dr. Jordi Caballé Serrano and Dr. Jianbo Peng for their essential help with the fluorescence microscopy and the Western blot analysis.

Conflict of interest The authors declare that they have no conflict of interest.

\section{References}

1. du Toit DF, Nortje C (2004) Salivary glands: applied anatomy and clinical correlates. SADJ 59:65-66, 69-71, 73-4

2. Cheaib Z, Lussi A (2011) Impact of acquired enamel pellicle modification on initial dental erosion. Caries Res 45:107-112. doi:10. $1159 / 000324803$

3. Jakubovics NS, Kolenbrander PE (2010) The road to ruin: the formation of disease-associated oral biofilms. Oral Dis 16:729-739. doi: 10.1111/j.1601-0825.2010.01701.x

4. Yao Y, Berg EA, Costello CE, Troxler RF, Oppenheim FG (2003) Identification of protein components in human acquired enamel pellicle and whole saliva using novel proteomics approaches. J Biol Chem 278:5300-5308. doi:10.1074/jbc.M206333200

5. Nobbs AH, Jenkinson HF, Jakubovics NS (2011) Stick to your gums: mechanisms of oral microbial adherence. J Dent Res 90:1271-1278. doi:10.1177/0022034511399096

6. Bodner L, Knyszynski A, Adler-Kunin S, Danon D (1991) The effect of selective desalivation on wound healing in mice. Exp Gerontol 26: 357-363

7. Bodner L, Dayan D, Rothchild D, Hammel I (1991) Extraction wound healing in desalivated rats. J Oral Pathol Med 20:176-178

8. Grossman N, Binyamin LA, Bodner L (2004) Effect of rat salivary glands extracts on the proliferation of cultured skin cells - a wound healing model. Cell Tissue Bank 5:205-212. doi:10.1007/s10561004-4367-7

9. Proksch S, Steinberg T, Keller C, Wolkewitz M, Wiedmann-AlAhmad M, Finkenzeller G, Hannig C, Hellwig E, Al-Ahmad A (2012) Human saliva exposure modulates bone cell performance in vitro. Clin Oral Investig 16:69-77. doi:10.1007/s00784-0100506-7

10. Komine K, Kuroishi T, Ozawa A, Komine Y, Minami T, Shimauchi H, Sugawara S (2007) Cleaved inflammatory lactoferrin peptides in parotid saliva of periodontitis patients. Mol Immunol 44:1498-1508. doi:10.1016/j.molimm.2006.09.003

11. Ohshima M, Sato M, Ishikawa M, Maeno M, Otsuka K (2002) Physiologic levels of epidermal growth factor in saliva stimulate cell migration of an oral epithelial cell line, HO-1-N-1. Eur J Oral Sci 110: $130-136$

12. Humphreys-Beher MG, Macauley SP, Chegini N, van Setten G, Purushotham K, Stewart C, Wheeler TT, Schultz GS (1994) Characterization of the synthesis and secretion of transforming growth factor-alpha from salivary glands and saliva. Endocrinology 134:963-970

13. Oudhoff MJ, Bolscher JG, Nazmi K, Kalay H, van 't Hof W, Amerongen AV, Veerman EC (2008) Histatins are the major wound-closure stimulating factors in human saliva as identified in a cell culture assay. FASEB J 22:3805-3812. doi:10.1096/fj.08112003

14. Kato T, Imatani T, Minaguchi K, Saitoh E, Okuda K (2002) Salivary cystatins induce interleukin-6 expression via cell surface molecules in human gingival fibroblasts. Mol Immunol 39:423-430 
15. Pradhan L, Cai X, Wu S, Andersen ND, Martin M, Malek J, Guthrie P, Veves A, Logerfo FW (2011) Gene expression of proinflammatory cytokines and neuropeptides in diabetic wound healing. J Surg Res 167:336-342. doi:10.1016/j.jss.2009.09.012

16. Papanicolaou DA, Wilder RL, Manolagas SC, Chrousos GP (1998) The pathophysiologic roles of interleukin-6 in human disease. Ann Intern Med 128:127-137

17. Baggiolini M, Walz A, Kunkel SL (1989) Neutrophil-activating peptide-1/interleukin 8, a novel cytokine that activates neutrophils. J Clin Invest 84:1045-1049. doi:10.1172/JCI114265

18. Scheres N, Laine ML, de Vries TJ, Everts V, van Winkelhoff AJ (2010) Gingival and periodontal ligament fibroblasts differ in their inflammatory response to viable Porphyromonas gingivalis. J Periodontal Res 45:262-270. doi:10.1111/j.16000765.2009.01229.x

19. Uehara A, Takada H (2007) Functional TLRs and NODs in human gingival fibroblasts. J Dent Res 86:249-254

20. Gornowicz A, Bielawska A, Bielawski K, Grabowska SZ, Wojcicka A, Zalewska M, Maciorkowska E (2012) Pro-inflammatory cytokines in saliva of adolescents with dental caries disease. Ann Agric Environ Med AAEM 19:711-716

21. Ertugrul AS, Sahin H, Dikilitas A, Alpaslan N, Bozoglan A (2013) Comparison of CCL28, interleukin-8, interleukin-1beta and tumor necrosis factor-alpha in subjects with gingivitis, chronic periodontitis and generalized aggressive periodontitis. J Periodontal Res 48:44-51. doi:10.1111/j.1600-0765.2012.01500.x

22. Scott AE, Milward M, Linden GJ, Matthews JB, Carlile MJ, Lundy FT, Naeeni MA, Lorraine Martin S, Walker B, Kinane D, Brock GR, Chapple IL (2012) Mapping biological to clinical phenotypes during the development (21 days) and resolution (21 days) of experimental gingivitis. J Clin Periodontol 39:123-131. doi:10.1111/j.1600-051X. 2011.01825.x

23. Teles RP, Likhari V, Socransky SS, Haffajee AD (2009) Salivary cytokine levels in subjects with chronic periodontitis and in periodontally healthy individuals: a cross-sectional study. J Periodontal Res 44:411-417. doi:10.1111/j.1600-0765.2008.01119.x

24. Severino VO, Napimoga MH, de Lima Pereira SA (2011) Expression of IL-6, IL-10, IL-17 and IL-8 in the peri-implant crevicular fluid of patients with peri-implantitis. Arch Oral Biol 56:823-828. doi:10. 1016/j.archoralbio.2011.01.006

25. Groschl M (2009) The physiological role of hormones in saliva. Bioessays 31:843-852. doi:10.1002/bies.200900013

26. Services USDoHaH (2004) Guidance for industry, sterile drug products produced by aseptic processing — current good manufacturing practice. FDA, Rockville

27. Jin J, Sundararaj KP, Samuvel DJ, Zhang X, Li Y, Lu Z, LopesVirella MF, Huang Y (2012) Different signaling mechanisms regulating IL-6 expression by LPS between gingival fibroblasts and mononuclear cells: seeking the common target. Clin Immunol 143: 188-199. doi:10.1016/j.clim.2012.01.019

28. Hwang YS, Lee SK, Park KK, Chung WY (2012) Secretion of IL-6 and IL-8 from lysophosphatidic acid-stimulated oral squamous cell carcinoma promotes osteoclastogenesis and bone resorption. Oral Oncol 48:40-48. doi:10.1016/j.oraloncology.2011.08.022

29. Tang CH, Hsu CJ, Yang WH, Fong YC (2010) Lipoteichoic acid enhances IL-6 production in human synovial fibroblasts via TLR2 receptor, PKCdelta and c-Src dependent pathways. Biochem Pharmacol 79:1648-1657. doi:10.1016/j.bcp.2010.01.025

30. Thomadaki K, Helmerhorst EJ, Tian N, Sun X, Siqueira WL, Walt DR, Oppenheim FG (2011) Whole-saliva proteolysis and its impact on salivary diagnostics. J Dent Res 90:1325-1330. doi:10.1177/ 0022034511420721

31. Miyazono K, Hellman U, Wernstedt C, Heldin CH (1988) Latent high molecular weight complex of transforming growth factor beta 1. Purification from human platelets and structural characterization. J Biol Chem 263:6407-6415

32. Takanashi N, Tomosada Y, Villena J, Murata K, Takahashi T, Chiba E, Tohno M, Shimazu T, Aso H, Suda Y, Ikegami S, Itoh H, Kawai Y, Saito T, Alvarez S, Kitazawa H (2013) Advanced application of bovine intestinal epithelial cell line for evaluating regulatory effect of lactobacilli against heat-killed enterotoxigenic Escherichia coli-mediated inflammation. BMC Microbiol 13:54. doi:10.1186/1471-2180-13-54

33. Yan W, Apweiler R, Balgley BM, Boontheung P, Bundy JL, Cargile BJ, Cole S, Fang X, Gonzalez-Begne M, Griffin TJ, Hagen F, Hu S, Wolinsky LE, Lee CS, Malamud D, Melvin JE, Menon R, Mueller M, Qiao R, Rhodus NL, Sevinsky JR, States D, Stephenson JL, Than S, Yates JR, Yu W, Xie H, Xie Y, Omenn GS, Loo JA, Wong DT (2009) Systematic comparison of the human saliva and plasma proteomes. Proteomics Clin Appl 3:116-134. doi:10.1002/prca.200800140

34. Loo JA, Yan W, Ramachandran P, Wong DT (2010) Comparative human salivary and plasma proteomes. J Dent Res 89:1016-1023. doi:10.1177/0022034510380414

35. Odqvist L, Sanchez-Beato M, Montes-Moreno S, Martin-Sanchez E, Pajares R, Sanchez-Verde L, Ortiz-Romero PL, Rodriguez J, Rodriguez-Pinilla SM, Iniesta-Martinez F, Solera-Arroyo JC, Ramos-Asensio R, Flores T, Palanca JM, Bragado FG, Franjo PD, Piris MA (2013) NIK controls classical and alternative NF-kappaB activation and is necessary for the survival of human T-cell lymphoma cells. Clin Cancer Res Off J Am Assoc Cancer Res 19:2319 2330. doi:10.1158/1078-0432.CCR-12-3151

36. Abend JR, Uldrick T, Ziegelbauer JM (2010) Regulation of tumor necrosis factor-like weak inducer of apoptosis receptor protein (TWEAKR) expression by Kaposi's sarcoma-associated herpesvirus microRNA prevents TWEAK-induced apoptosis and inflammatory cytokine expression. J Virol 84:12139-12151. doi:10.1128/JVI. 00884-10 